ASTHMA

\title{
Association between polymorphism of tumour necrosis factor $\alpha-308$ gene promoter and asthma: a meta-analysis
}

\author{
J Gao, G Shan, B Sun, P J Thompson, X Gao
}

Background: Asthma is a complex polygenic disease in which gene-environment interactions are important. The gene encoding tumour necrosis factor alpha (TNF $\alpha)$ is one of several candidate loci for asthma pathogenesis and is highly polymorphic. A number of studies have investigated the polymorphism of TNF $\alpha-308$ gene promoter (substitution $\mathrm{G} \rightarrow \mathrm{A}$, designated as TNF1 and TNF2) in relation to asthma susceptibility in different populations. However, the results of individual studies have been inconsistent. Methods: To address the inconsistent findings in studies of the association of the polymorphism of TNF $\alpha$ 308 gene promoter with susceptibility to asthma, a systematic review was undertaken of the published data and a meta-analysis was performed. The MEDLINE database was searched for case-control studies published in English language journals from 1966 to October 2005. Data were extracted using standardised forms and pooled odds ratios (ORs) with $95 \%$ confidence intervals $(\mathrm{Cls})$ were calculated.

See end of article for authors' affiliations

Correspondence to: Dr J Gao, Department of Respiratory Diseases, Peking Union Medical College Hospital, 1 Shuaituyuan, Dongcheng District, Beiiing 100730, China; gaojm@pumch.ac. $\mathrm{cn}$

Received 9 August 2005 Accepted 6 February 2006 Published Online First 3 March 2006 Results: Fifteen eligible studies, comprising 2409 patients with asthma and 3266 controls, were included in the meta-analysis. Using the random effects model, the pooled result showed that the TNF2 allele is associated with overall susceptibility to asthma (OR $1.37,95 \% \mathrm{Cl} 1.02$ to $1.84, \mathrm{p}=0.04$ ). The ORs for asthma susceptibility in TNF2 homozygote individuals were significantly increased at $2.01195 \% \mathrm{Cl} 1.26$ to $3.20, p=0.009)$ and 1.51 (95\% Cl 1.02 to 2.22, $p=0.041)$ compared with TNF1 homozygotes and TNF2/ 1 heterozygotes, respectively. In addition, the pooled OR for asthma risk in TNF2/ 1 heterozygotes was also significantly higher than that in TNF1/1 homozygotes (OR 1.47, 95\% Cl 1.01 to 2.13, $\mathrm{p}=0.045$ ).

Conclusions: The TNF2 allele confers a significant risk for developing asthma. A large scale case-control study is needed to clarify the functional effect of the polymorphism of the TNF $\alpha$ gene in the pathogenesis of asthma.

A sthma is a complex disorder characterised by airway inflammation that involves the interaction of genetic and environmental factors. The genes predisposing to asthma are likely to contain polymorphisms that modify function. Tumour necrosis factor alpha $(\mathrm{TNF} \alpha)$ is a potent inflammatory cytokine whose encoding gene lies on the short arm of chromosome $6 .{ }^{1}$ The TNF $\alpha$ gene may influence asthma through modulation of non-specific inflammation. ${ }^{2}$ The $\mathrm{TNF} \alpha-308$ promoter polymorphism is a bi-allelic $\mathrm{G}$ (named TNF1 allele) to A (named TNF2 allele) polymorphism, ${ }^{3}$ and the TNF2 allele is associated with increased levels of TNF $\alpha$ in plasma and bronchoalveolar lavage fluid from asthmatic airways. ${ }^{45}$ Thus, the central role of airway inflammation in asthma and the increased levels of TNF $\alpha$ in asthmatic lungs suggest that functional variants of the TNF $\alpha$ gene could be important in this disease.

A number of studies have assessed the association between the TNF $\alpha-308$ promoter polymorphism and asthma in different populations; however, the results are inconsistent and inconclusive. ${ }^{6-25}$ Different methodologies have been used but, in particular, most of the studies used a small sample size and it is therefore not surprising that there has been a lack of replication between the various studies. By using all the available published data to increase the statistical power, it was hypothesised that a meta-analysis might allow plausible candidate genes to be excluded and causative genes to be identified with reliability. We therefore performed a meta-analysis of all of the published case-control studies to ascertain whether the polymorphisms of TNF $\alpha-308$ gene promoter increased the risk of asthma.

\section{METHODS}

\section{Study selection}

The MEDLINE database was comprehensively searched (last updated search being October 2005) using PubMed and Highwire search engines. The keywords used were as follows: asthma, asthma genetics, tumour necrosis factor AND polymorphism or variant or genotype. We also manually searched the reference lists of relevant publications for additional studies.

To be included in the meta-analysis, studies had to meet the following criteria: (1) the design had to be a case-control study; (2) the outcome had to be asthma; and (3) there had to be at least two comparison groups (asthma $v$ control groups). Participants could be of any age. Studies were excluded if one of the following existed: (1) the design was based on family or sibling pairs; (2) the genotype frequency was not reported; or (3) there was insufficient information for extraction of data.

The asthma definition used in the individual studies was accepted and we documented this in our analysis.

\section{Data extraction and inclusion criteria}

A standardised reporting form was used to abstract the data from each publication including: first author's name, year of publication, country in which the study was conducted, ethnicity, study design, age range of study subjects, sample size, asthma definition, asthma related phenotypes, and

Abbreviation: $\mathrm{TNF} \alpha$, tumour necrosis factor alpha 
Table 1 Characteristics of 15 publications included in meta-analysis of TNF $\alpha-308$ polymorphism and asthma susceptibility

\begin{tabular}{|c|c|c|c|c|c|c|c|}
\hline Reference & Country & Ethnicity & Age & $\begin{array}{l}\text { Source of } \\
\text { cases (n) }\end{array}$ & $\begin{array}{l}\text { Source of } \\
\text { controls (n) }\end{array}$ & Asthma definition & $\begin{array}{l}\text { Hardy-Weinberg } \\
\text { equilibrium }\end{array}$ \\
\hline Moffatt $^{6}$ & Australia & Caucasian & $5-51$ years & $\begin{array}{l}\text { General population } \\
\text { (92) }\end{array}$ & $\begin{array}{l}\text { General population without } \\
\text { asthma (318) }\end{array}$ & $\begin{array}{l}\text { Respiratory } \\
\text { questionnaire }\end{array}$ & Yes \\
\hline Chagni $^{9}$ & Canada & Caucasian & $<50$ years & Hospital patients (251) & Blood donors (252) & Asthma severity & Yes \\
\hline Li Kam Wa ${ }^{10}$ & UK & Mixed race & 18-70 years & Local community (246) & $\begin{array}{l}\text { Random individuals } \\
\text { (310) }\end{array}$ & Symptom, BHR & Yes \\
\hline Louis" & Belgium & Caucasian & $17-74$ years & $\begin{array}{l}\text { Hospital outpatient } \\
\text { clinic (95) }\end{array}$ & $\begin{array}{l}\text { Hospital workers and blood } \\
\text { donors (98) }\end{array}$ & $\begin{array}{l}\text { Symptoms, BHR or } \\
\text { positive airway } \\
\text { reversibility }\end{array}$ & Yes \\
\hline Winchester $^{12}$ & UK & $\begin{array}{l}\text { Caucasian, } \\
\text { South Asian }\end{array}$ & Adults & Hospital clinic (26) & Non-asthmatics (691) & $\begin{array}{l}\text { History of childhood } \\
\text { asthma }\end{array}$ & Yes \\
\hline Zhu ${ }^{13}$ & Canada & Caucasian & Infants & Hospital clinic (12) & Non-asthmatics (269) & Symptom & Yes \\
\hline Witte $^{15}$ & USA & Mixed race & $28-56$ years & Outpatient clinic (236) & Non-asthmatics (275) & $\begin{array}{l}\text { Doctor's diagnosis } \\
\text { with positive airway } \\
\text { reversibility }\end{array}$ & Yes \\
\hline Buckova $^{16}$ & Czech & Caucasian & $14-44$ years & $\begin{array}{l}\text { Practitioners' offices } \\
\text { (151) }\end{array}$ & $\begin{array}{l}\text { Controls without atopy, lung } \\
\text { disorders (155) }\end{array}$ & ATS diagnosis criteria & Yes \\
\hline $\mathrm{Gao}^{17}$ & China & Chinese & Adults & $\begin{array}{l}\text { Hospital pulmonary } \\
\text { clinic (125) }\end{array}$ & Healthy controls (96) & $\begin{array}{l}\text { Doctor's diagnosis with } \\
\text { BHR and/or positive } \\
\text { airway reversibility }\end{array}$ & Yes \\
\hline Di Somma ${ }^{18}$ & Italy & Italian & $11-58$ years & Hospital clinic (70) & Non-asthmatics (169) & Questionnaire & Yes \\
\hline Beghe $^{19}$ & Italy & Italian & Adults & $\begin{array}{l}\text { Pulmonary clinics } \\
\text { (142) }\end{array}$ & $\begin{array}{l}\text { Asymptomatics exposed to } \\
\text { TDI (50) }\end{array}$ & TDI-induced asthma & No $(p=0.018)$ \\
\hline Sandford ${ }^{21}$ & Hongkong & Chinese & 10 years & $\begin{array}{l}\text { ISAAC phase II study } \\
\text { (107) }\end{array}$ & Schoolchildren (118) & $\begin{array}{l}\text { Questionnaire, } \\
\text { spirometry, BHR testing }\end{array}$ & Yes \\
\hline $\operatorname{Shin}^{22}$ & Korea & Korean & $7-80$ years & $\begin{array}{l}\text { Asthma research centre } \\
\text { (550) }\end{array}$ & $\begin{array}{l}\text { Normal subjects } \\
\text { excluding asthma (171) }\end{array}$ & $\begin{array}{l}\text { Doctor's diagnosis with } \\
\text { BHR and/or positive } \\
\text { airway reversibility }\end{array}$ & Yes \\
\hline Wang $^{23}$ & China & Chinese & Children & Hospital clinics (191) & Community population (138) & Questionnaire & Yes \\
\hline Bilolikar $^{24}$ & UK & Caucasian & $2-17$ years & $\begin{array}{l}\text { Hospital respiratory } \\
\text { clinics (115) }\end{array}$ & Normal controls (156) & Doctor's diagnosis & Yes \\
\hline
\end{tabular}

genotyping methods used. Data were extracted independently and in duplicate by two investigators (JMG and GLS). The results were compared and disagreements were resolved by consensus.

\section{Statistical analysis}

A logistic regression model was used to assess the overall genetic effect of the TNF $\alpha$-308 gene on having asthma. To examine the risk of asthma with a specific polymorphism of the $\mathrm{TNF} \alpha-308$ gene, we pooled the odds ratios (ORs) from each study weighted by the inverse of variance. A random effects model was used for the analysis which considered both within- and between-study variation. ${ }^{26}$ The effects of ethnicity on the pooled ORs were examined with the metaregression method. ${ }^{27}{ }^{28}$ Sensitivity analysis was conducted to examine whether the inclusion criteria affected the pooled ORs. We included the study by Beghe, ${ }^{19}$ which has been shown to be in Hardy-Weinberg disequilibrium $(p=0.018)$.

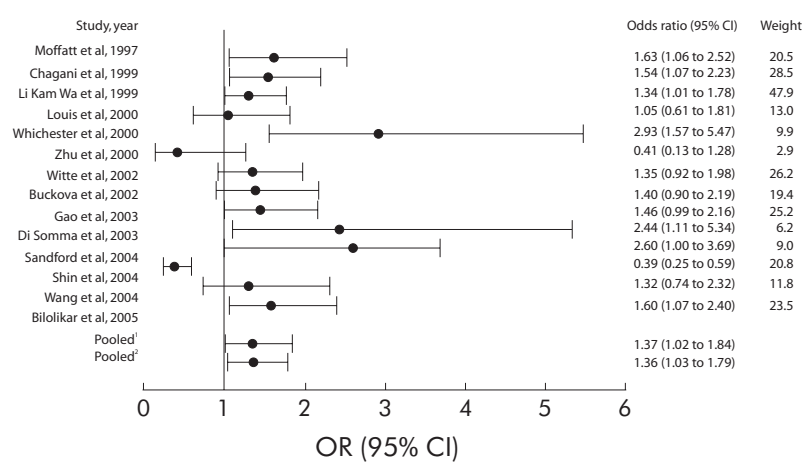

Figure 1 Odds ratios for asthma comparing any TNF2 allele with TNF1 allele. (1) Pooled odds ratios excluding Beghe's study $(n=14)$. (2) Pooled odds ratios including Beghe's study $(n=15)$. OR, odds ratios, $\mathrm{Cl}$, confidence interval.

Table 2 Association between TNF2 allele and asthma

\begin{tabular}{|c|c|c|c|c|c|c|c|c|c|c|c|c|}
\hline \multirow[b]{2}{*}{ Reference } & \multicolumn{2}{|c|}{ TNF2 vs TNF1 } & \multicolumn{2}{|c|}{ TNF2/2 vs TNF1/1 } & \multicolumn{2}{|c|}{ TNF2/ 2 vs TNF2/ 1} & \multicolumn{2}{|c|}{ TNF2/ 1 vs TNF1/1 } & \multicolumn{2}{|c|}{ TNF $\alpha-308+$} & \multicolumn{2}{|c|}{ LT $\alpha$ Ncol+ } \\
\hline & OR & $95 \% \mathrm{Cl}$ & OR & $95 \% \mathrm{Cl}$ & OR & $95 \% \mathrm{Cl}$ & OR & $95 \% \mathrm{Cl}$ & 1 & 2 & 1 & 2 \\
\hline Moffatt $^{6}$ & 1.63 & 1.06 to 2.52 & 3.20 & 1.23 to 8.28 & 1.65 & 0.63 to 4.37 & 1.94 & 1.17 to 3.22 & - & + & + & - \\
\hline Chagni $^{9}$ & 1.54 & 1.07 to 2.23 & & & & & & & - & + & & \\
\hline $\mathrm{Li} \mathrm{Kam}^{10}$ & 1.34 & 1.01 to 1.78 & 2.21 & 1.07 to 4.56 & 1.97 & 0.93 to 4.16 & 1.12 & 0.78 to 1.61 & - & + & & \\
\hline Louis $^{11}$ & 1.05 & 0.61 to 1.81 & & & & & 1.24 & 0.67 to 2.30 & NS & NS & & \\
\hline Winchester $^{12}$ & 2.93 & 1.53 to 5.47 & 4.02 & 0.85 to 19.00 & 1.36 & 0.28 to 6.56 & 2.96 & 1.30 to 6.75 & - & + & & \\
\hline$Z \mathrm{Zh}^{13}$ & 0.41 & 0.13 to 1.28 & & & & & 2.06 & 0.51 to 8.24 & NS & NS & & \\
\hline Witte $^{15}$ & 1.35 & 0.92 to 1.98 & 0.86 & 0.24 to 3.10 & 0.55 & 0.15 to 2.04 & 1.58 & 1.04 to 2.37 & - & + & NS & NS \\
\hline Buckova $^{16}$ & 1.40 & 0.90 to 2.19 & 3.41 & 0.35 to 33.32 & 2.48 & 0.25 to 24.80 & 1.38 & 0.83 to 2.28 & NS & NS & NS & NS \\
\hline $\mathrm{Gao}^{17}$ & 1.46 & 0.99 to 2.16 & 2.21 & 0.98 to 5.01 & 1.87 & 0.82 to 4.20 & 1.19 & 0.66 to 2.12 & - & + & NS & NS \\
\hline Di Somma ${ }^{18}$ & 2.44 & 1.11 to 5.34 & & & & & & & NS & NS & & \\
\hline Beghe $^{19}$ & 1.27 & 0.58 to 2.74 & & & & & & & NS & NS & & \\
\hline Sandford ${ }^{21}$ & 2.60 & 1.00 to 3.69 & & & & & 2.07 & 1.04 to 4.12 & - & + & & \\
\hline $\operatorname{Shin}^{22}$ & 0.39 & 0.25 to 0.59 & 0.27 & 0.04 to 1.95 & 0.74 & 0.10 to 5.50 & & & + & - & NS & NS \\
\hline Wang $^{23}$ & 1.32 & 0.74 to 2.32 & & & & & 2.16 & 1.19 to 3.91 & - & + & NS & NS \\
\hline Bilolikar $^{24}$ & 1.60 & 1.07 to 2.40 & 1.60 & 0.50 to 5.07 & 0.77 & 0.24 to 2.51 & 2.08 & 1.15 to 3.75 & - & + & - & + \\
\hline
\end{tabular}

,+ A significant $(p<0.05)$ association with the + allele increased and the - allele decreased in asthmatics; $1=G, 2=A$; NS, not significant difference. 
Table 3 Genotype frequencies of TNF $\alpha-308$ gene polymorphism in asthma and control groups

\begin{tabular}{|c|c|c|c|c|c|c|c|c|}
\hline \multirow[b]{3}{*}{ Reference } & \multicolumn{4}{|l|}{ Asthma group } & \multicolumn{4}{|l|}{ Control group } \\
\hline & \multirow[b]{2}{*}{$\%$ with TNF2 } & \multicolumn{3}{|c|}{ Genotype (n) } & \multirow[b]{2}{*}{$\%$ with TNF2 } & \multicolumn{3}{|c|}{ Genotype (n) } \\
\hline & & TNF2/2 & TNF2/1 & TNF $1 / 1$ & & TNF2/2 & TNF2/1 & TNF $1 / 1$ \\
\hline Moffatt $^{6}$ & 30 & 8 & 36 & 44 & 18 & 12 & 89 & 211 \\
\hline Chagni ${ }^{9}$ & 20 & 100 & & 150 & 15 & 76 & & 176 \\
\hline Li Kam $\mathrm{Wa}^{10}$ & 26 & 21 & 87 & 139 & 21 & 13 & 106 & 190 \\
\hline Louis $^{11}$ & 16 & 2 & 27 & 69 & 15 & 0 & 31 & 64 \\
\hline Winchester $^{12}$ & 29 & 2 & 11 & 13 & 27 & 20 & 149 & 522 \\
\hline Zhu ${ }^{13}$ & 17 & 0 & 4 & 8 & 14 & 2 & 25 & 81 \\
\hline Witte $^{15}$ & 18 & 4 & 67 & 164 & 14 & 6 & 55 & 212 \\
\hline Buckova $^{16}$ & 17.2 & 3 & 46 & 102 & 12.9 & 1 & 38 & 116 \\
\hline $\mathrm{Gao}^{17}$ & 42 & 26 & 52 & 47 & 33 & 11 & 41 & 44 \\
\hline Di Somma ${ }^{18}$ & 40 & NA & & & 22 & NA & & \\
\hline Beghe $^{19}$ & 12 & 1 & 32 & 109 & 11 & 1 & 8 & 36 \\
\hline Sandford ${ }^{21}$ & 12 & 0 & 26 & 80 & 7 & 0 & 16 & 102 \\
\hline $\operatorname{Shin}^{22}$ & 5 & 2 & 50 & 482 & 12 & 2 & 37 & 131 \\
\hline Wang $^{23}$ & 14 & 2 & 49 & 140 & 7 & 0 & 18 & 111 \\
\hline Bilolikar $^{24}$ & 30 & 8 & 50 & 50 & 21 & 9 & 46 & 94 \\
\hline
\end{tabular}

We then compared the pooled ORs with the results from the main analysis.

Heterogeneity among studies was examined with the Q, H, and $\mathrm{I}^{2}$ statistics. ${ }^{29} \mathrm{~A} p$ value of $<0.1$ was consider significant for the $\mathrm{Q}$ statistic; $\mathrm{H}<1.2$ suggested no heterogeneity among studies; and $\mathrm{I}^{2}$ was interpreted as the proportion of total variation contributed by between-study variation. Publication bias was examined with funnel plots and with the Begg test and Egger test. ${ }^{30-32}$ If there is evidence of publication bias, the funnel plot is noticeably asymmetric. For the Begg and Egger test the significance level was set at 0.1. Statistical analyses were performed with SAS statistical software Version 8.2 (SAS Inc, Cary, NC, USA).

\section{RESULTS}

\section{Characteristics of included studies}

We identified 23 publications that had evaluated the association of $\mathrm{TNF} \alpha-308$ gene polymorphism with asthma. Eight studies were excluded for the following reasons: sibling paired and family based study design $(\mathrm{n}=2),{ }^{825}$ no allele or genotyping frequency $(\mathrm{n}=3),{ }^{71420}$ and analysis of the TNF $\beta$ (lymphotoxin- $\alpha, \mathrm{LT} \alpha$ ) NcoI polymorphism rather than TNF $\alpha$ $(\mathrm{n}=5)$. $^{33-37}$

Fifteen original case-control studies, comprising 2409 patients with asthma and 3266 controls, were included in

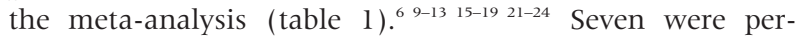
formed in Caucasian subjects, ${ }^{6}{ }^{11-131624}$ two in Italian subjects, $^{18}{ }^{19}$ four in East Asian populations, ${ }^{17}{ }^{21-23}$ one in a South Asian population, ${ }^{12}$ and two in a mixed race cohort. ${ }^{10}{ }^{15}$ Four studies involved paediatric subjects alone, ${ }^{13212324}$ three included both children and adults, ${ }^{6}{ }^{1822}$ and eight recruited adults only. ${ }^{9-12}$ 15-17 $19^{19}$ Seven studies extended their examination to the TNF $\alpha$ neighbouring gene lymphotoxin (LT) $\alpha$ variant and asthma; ${ }^{615-1722-24}$ two of these showed an association between LT $\alpha$ NcoI polymorphism with asthma. ${ }^{624}$

PCR based genotyping method was mentioned in each study. Four studies particularly stated that double blind genotyping was conducted. ${ }^{610} 1213$

\section{Association between TNF2 allele and asthma}

Nine studies found a positive association between TNF2 and asthma (table 2). ${ }^{6} 910121517212324$ Five studies reported a negative association, ${ }^{11} 13161819$ and one study reported a positive association between TNF1 and asthma. ${ }^{22}$ Nine of 15 publications indicated Hardy-Weinberg equilibrium in their subjects; ${ }^{11} 12161721-24$ we calculated Hardy-Weinberg equilibrium for the remaining six publications and found that only
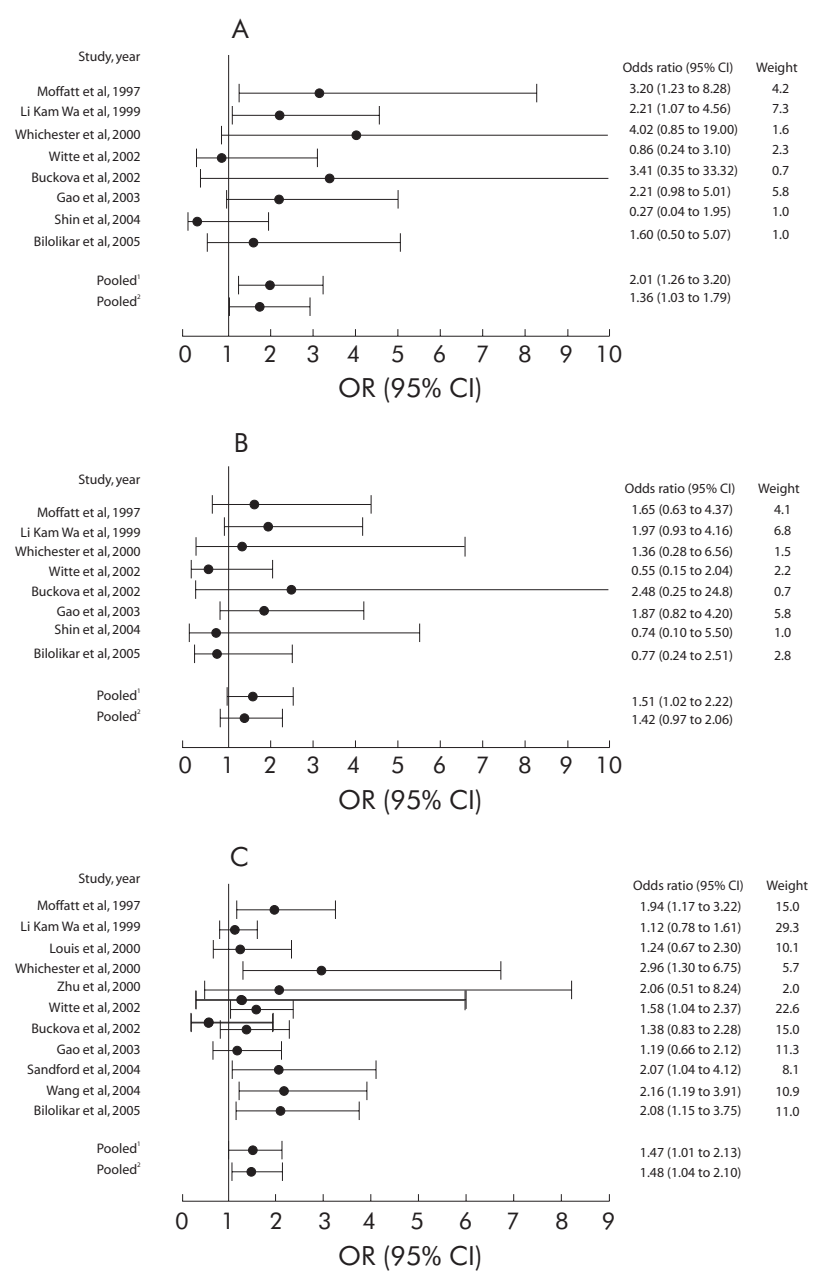

Figure 2 (A) Odds ratios for asthma comparing TNF2/2 homozygotes with TNF1/1 homozygotes.: (1) pooled odds ratios excluding Beghe's study $(n=8)$; (2) pooled odds ratios including Beghe's study $(n=9)$. (B) Odds ratios for asthma comparing TNF2/2 homozygotes with TNF2/1 heterozygotes: (1) pooled odds ratios excluding Beghe's study $(n=8)$; (2) pooled odds ratios including Beghe's study ( $\mathrm{n}=9)$. (C) Odds ratios for asthma comparing TNF2/1 heterozygotes with TNF1/1

homozygotes: (1) pooled odds ratios excluding Beghe's study $(n=11)$;

(2) pooled odds ratios including Beghe's study $(n=12)$. OR, odds ratios; $\mathrm{Cl}$, confidence intervals. 
Table 4 Pooled odds ratios for TNF $\alpha-308$ gene polymorphism and asthma susceptibility in meta-analyses: comparisons of alleles and genotypes

\begin{tabular}{|c|c|c|c|c|c|c|c|c|}
\hline \multirow[b]{2}{*}{ Comparison } & \multirow{2}{*}{$\begin{array}{l}\text { No of } \\
\text { studies }\end{array}$} & \multirow[b]{2}{*}{ OR $(95 \% \mathrm{Cl})$} & \multirow[b]{2}{*}{ p value* } & \multicolumn{2}{|c|}{ Publication bias } & \multicolumn{3}{|c|}{ Heterogeneity test† } \\
\hline & & & & Egger & Begg & $p$ & $I^{2}$ & H \\
\hline TNF2 $v$ TNF1 & 14 & 1.37 (1.02 to 1.84$)$ & 0.04 & $p>0.2$ & $p>0.2$ & $<0.01$ & 0.75 & 1.98 \\
\hline $\mathrm{TNF} 2 / 2 v \mathrm{TNF} 1 / 1$ & 8 & 2.01 (1.26 to 3.20$)$ & 0.009 & $p>0.2$ & $p>0.2$ & 0.029 & 0.53 & 1.46 \\
\hline $\mathrm{TNF} 2 / 2 v \mathrm{TNF} 2 / 1$ & 8 & 1.51 (1.02 to 2.22$)$ & 0.041 & $p>0.2$ & $p>0.2$ & $>0.1$ & 0 & 1 \\
\hline $\mathrm{TNF} 2 / 1 \vee \mathrm{TNF} 1 / 1$ & 11 & $1.47(1.01$ to 2.13$)$ & 0.045 & $p>0.2$ & $p=0.04$ & $<0.01$ & 0.74 & 1.97 \\
\hline
\end{tabular}

OR, odds ratio; $\mathrm{Cl}$, confidence interval.

*Random effects models were used, weighted by the inverse variance. All statistical tests are two sided.

$\mathrm{tp}<0.1$ is considered statistically significant for $\mathrm{Q}$ statistics; $\mathrm{I}^{2}$ is interpreted as the proportion of total variation contributed by between-study variation; $\mathrm{H}<1.2$

suggests no heterogeneity among studies.

the study by Beghe was in Hardy-Weinberg disequilibrium $(\mathrm{p}=0.018) .{ }^{19}$

There was a statistically significant heterogeneity among the ORs in the included studies ( $\mathrm{Q}$ test: $\mathrm{p}<0.01 ; \mathrm{H}=1.98$; $\left.\mathrm{I}^{2}=0.75\right)$. When the study by Beghe was not included, the overall pooled OR for asthma susceptibility was 1.37 (95\% CI 1.02 to $1.84, \mathrm{p}=0.04$ ) for TNF2 carriers compared with TNF1 carriers. When Beghe's study was included, the overall pooled OR did not change (OR 1.36, 95\% CI 1.03 to $1.79, \mathrm{p}=0.03$; fig 1).

\section{Association between genotypes of TNF $\alpha-308$ and asthma}

Thirteen publications reported the genotype frequency of TNF $\alpha-308$ in asthmatics and controls (table 3). Eight publications that observed Hardy-Weinberg equilibrium were pooled to examine the effect of TNF $2 / 2$ homozygote on asthma susceptibility. The overall genetic effect using logistic regression showed that the polymorphisms of $\mathrm{TNF} \alpha-308$ were significantly associated with a risk of having asthma $(\mathrm{p}<0.01)$. The pooled OR was increased at $2.01 \quad(95 \%$ CI 1.26 to $3.20, \mathrm{p}=0.009$ ) for individuals carrying the TNF2/2 homozygote compared with individuals carrying the TNF1/l homozygote, and there was statistically significant heterogeneity among studies ( $\mathrm{Q}$ test: $\mathrm{p}=0.029 ; \mathrm{H}=1.53 ; \mathrm{I}^{2}=0.46$ ); if Beghe's study was included, the pooled OR was 1.74 (95\% CI 1.04 to 2.93, $\mathrm{p}=0.039$; fig $2 \mathrm{~A}$ ). The pooled $\mathrm{OR}$ was increased at $1.59(95 \%$ CI 0.99 to $2.55, \mathrm{p}=0.054)$ for individuals carrying the TNF2/2 homozygote compared with individuals carrying the TNF2/1 heterozygote and there was no heterogeneity among publications ( $\mathrm{Q}$ test: $\mathrm{p}>0.1 ; \mathrm{H}=1$; $\left.\mathrm{I}^{2}=0\right)$; if Beghe's study was included, the pooled OR was 1.38 (95\% CI 0.83 to $2.28, \mathrm{p}=0.184$; fig $2 \mathrm{~B}$ ).

We compared the influence of two major genotypesnamely, TNF2/1 heterozygote and TNF1/1 homozygote-on asthma in 12 publications. With the removal of Beghe's study, the pooled OR was increased at 1.47 (95\% CI 1.01 to 2.13, $\mathrm{p}=0.045)$ and there was statistically significant heterogeneity among the remaining 11 publications ( $Q$ test: $\left.\mathrm{p}<0.01 ; \mathrm{H}=1.97 ; \mathrm{I}^{2}=0.74\right)$. With inclusion of Beghe's study, the pooled OR was increased at 1.48 (95\% CI 1.04 to 2.10 , $\mathrm{p}=0.03$ ) (fig 2C).

There was little evidence of publication bias; $p$ values obtained from the Begg test and Egger test were $>0.2$ for all studies with the exception of the comparison between TNF2/ 1 heterogeneity and TNF1/1 homozygote $(p=0.04$, table 4$)$. However, funnel plots (fig 3A-D) showed some asymmetry, reflecting a relative absence of studies with both small numbers and larger effects for comparisons between TNF2 and TNF1 alleles, TNF2/2 homozygotes and TNF2/1

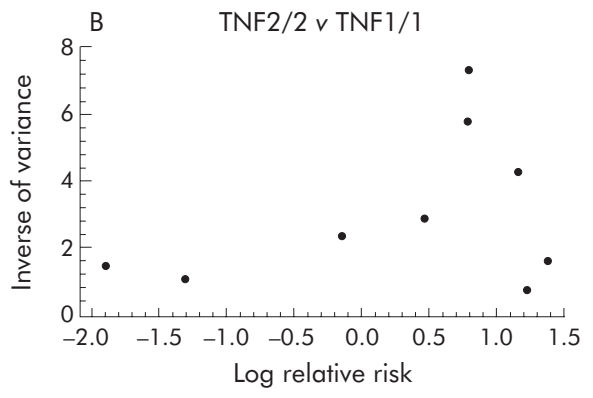

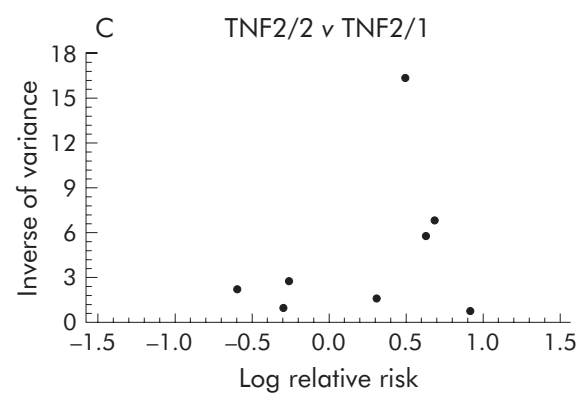
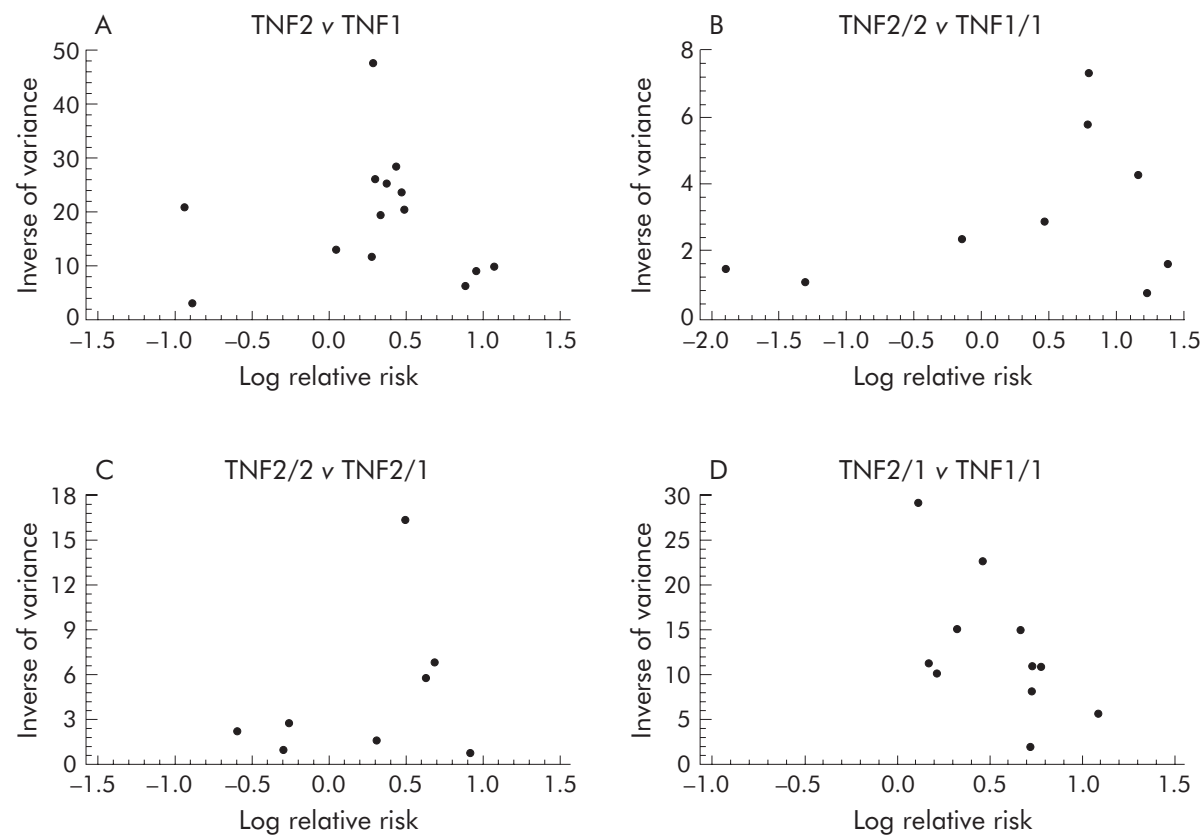

Figure 3 Funnel plots of the log relative risk (for the highest possibility of asthma versus the lowest possibility of asthma) versus the inverse of variance among (A) TNF2 allele $v$ TNF1 allele; (B) TNF 2/2 homozygote $v$ TNF 1/1 homozygote; (C) TNF2/2 homozygote $v$ TNF 2/1 heterozygote; and (D) TNF $2 / 1$ heterozygote $v$ TNF $1 / 1$ homozygote studies. 
heterozygotes, and TNF2/2 homozygotes and TNF2/1 heterozygotes. Equally, the studies of comparisons between TNF 2/1 heterozygotes and TNFl/l homozygotes had both small numbers and small or null effects.

\section{DISCUSSION}

The data from this meta-analysis clearly suggest that the TNF2 allele is a genetic contributor to overall asthma susceptibility. We observed that the TNF2/2 homozygote had a stronger association with asthma susceptibility than the TNF 2/1 heterozygote, indicating a dose response. These results suggest a possible beneficial role for the TNFl allele versus the TNF2 allele in asthma, as well as synergy of the TNF2-TNF2 alleles. The TNF2/2 homozygote represents a greater risk factor for the development of asthma. These findings are consistent with TNF $\alpha$ contributing to asthma inflammation both in vitro and in vivo. This reflects a direct functional effect of the TNF $\alpha$ gene through its upregulation of TNF $\alpha$ levels in asthma.

Based on known or presumed mechanisms of disease pathophysiology, candidate gene strategies provide a useful approach for evaluating gene-disease associations. However, candidate gene case-control studies have been criticised because of a lack of replication. Some TNF $\alpha$ studies have found positive associations between the TNF2 allele and asthma but others have not. Several factors may be influencing these differences. Firstly, if another variant in or near the TNF $\alpha$ gene was the causal variant, the true association could easily be missed. Different linkage disequilibrium patterns with the functional variant may lead to variable results in different populations. It is feasible that the $\mathrm{TNF} \alpha$ gene variant is playing a role in asthma in cooperation with other gene variants exhibiting a more limited biology. Previous studies have shown that there is a strong linkage disequilibrium between TNF $\alpha$ and LT $\alpha$ polymorphism (D/ Dmax $=1, \mathrm{p}<0.0001) .{ }^{38} \mathrm{~A}$ haplotype analysis by Bilolikar et $a l^{24}$ showed that the LT $\alpha 252 \mathrm{~A} / \mathrm{TNF} 2$ combination was associated with a markedly increased risk for both asthma and infant wheezing. The study by Randolph et al ${ }^{25}$ supported the suggestion that the haplotype LT $\alpha$-1/LT $\alpha$ 4371T/TNF1/ TNF1078G is associated with both asthma overall and asthmatic phenotypes. Of note, the TNF $\alpha$ gene is found within a $7 \mathrm{~kb}$ section of the informative major histocompatibility complex (MHC) class III region. Due to the close proximity of the TNF locus to HLA loci, linkage disequilibrium exists with several HLA alleles. For example, TNF2 is strongly associated with the HLA Al, B8 and DR3 alleles. ${ }^{39}$ Moreover, Moffatt et $\mathrm{al}^{7}$ found that the extended haplotype LT $\alpha-1 /$ TNF2/HLA-DRB2 was associated with asthma (OR $6.68, \mathrm{p}=0.002)$ and even more strongly associated with bronchial hyperresponsiveness (OR 21.9, $\mathrm{p}<0.0001)$ in a study of over 1000 patients.

Secondly, several asthma association studies have shown inconsistent results in Caucasian versus Asian populations. This suggests that there are racial differences in genetic risk, but the current evidence is that genetic effects are usually consistent across human populations. ${ }^{40}$ Small sample size, study design flaws, population stratification, genotyping error, and other biases may be more common reasons than true racial heterogeneity for the observed discrepancies between studies of genetic risks. ${ }^{41}$ Specific environmental exposures such as smoking or allergen exposure are another confounding factor for a disease with a strong geneenvironmental interaction in explaining the inconsistencies among observational studies. ${ }^{42} 43$

There are several limitations that should be considered when interpreting our results. Firstly, the pooled ORs were obtained from heterogeneous studies. Secondly, asthma itself is heterogeneous and thus the divergent inclusion criteria among patient groups might also lead to difficulties in pooling the various studies. Thirdly, our meta-analysis was restricted to English language publications. The fourth limitation is publication bias. Although significance tests did not suggest the presence of publication bias for most studies, funnel plots did not provide totally consistent results. The presence of possible bias could lead to an underestimation of the effect sizes of TNF2 allele $v$ TNF1 allele, TNF2/2 homozygote $v$ TNF2/1 heterozygote, and TNF $2 / 2$ homozygote $v$ TNF 2/1 heterozygote, but overestimation for TNF $2 / 1$ heterozygote $v$ TNF1/1 homozygote.

Our data suggest that the TNF2 allele may be a risk factor in the aetiology of asthma. The pooled ORs in this studyboth with respect to the TNF2 allele and the TNF2/2 homozygote-suggest a modest but definite genetic effect. A larger study population needs to be assessed to help answer the question of whether or not a given genetic variant confers susceptibility to specific asthma phenotypes. ${ }^{44}$ The early identification of children at genetic risk of asthma has the potential to offer new approaches to the prevention of asthma. The involvement of particular genes will identify particular clinical courses and anticipate response to treatment.

\section{ACKNOWLEDGEMENTS}

The authors thank Dr Youming Zhang for helpful suggestions.

\section{Authors' affiliations}

J Gao, Department of Respiratory Diseases, Peking Union Medical College Hospital, Peking Union Medical College \& Chinese Academy of Medical Sciences, Beijing 100730, China

G Shan, Department of Epidemiology and Biostatistics, Institute of Basic Medical Sciences, Peking Union Medical College \& Chinese Academy of Medical Sciences, Beijing 100005, China

B Sun, Hypertension and Atherosclerosis Section, Boston University School of Medicine, Boston, MA 02118, USA

P J Thompson, Asthma and Allergy Research Institute and Centre for Asthma, Allergy and Respiratory Research, University of Western Australia, Perth, WA 6009, Australia

$X$ Gao, Department of Nutrition, Harvard School of Public Health, Boston, MA 02115, USA

This work was in part funded by a grant from National Natural Sciences Foundation of China (No 30470767 to Jinming Gao). Jinming Gao is also supported by the Youth Fellowship from Peking Union Medical College Hospital. Philip J Thompson's involvement in this research was supported by the CRC for Asthma and Airways.

The authors declare no financial conflict in the preparation of this manuscript.

\section{REFERENCES}

1 Dunham I, Sargent CA, Trowsdale RL, et al. Molecular cloning of the human major histocompatibility complex by pulsed field electrophoresis. Proc Natl Acad Sci USA 1987;84:7237-41.

2 Thomas PS. Tumor necrosis factor- $\alpha$ : the role of this multifunctional cytokine in asthma. Immunol Cell Biol 2001;79:132-40.

3 Wilson AG, di Giovine FS, Blakemore Al, et al. Single base polymorphism in the human tumour necrosis factor alpha (TNF- $\alpha$ ) gene detectable by $\mathrm{Ncol}$ restriction of PCR product. Hum Mol Genet 1992;1:353.

4 Kebanoff, SJ, Vadas MS, Harian, JM. Stimulation of neutrophils by tumor necrosis factor. J Immunol 1986; 136:4220-5.

5 Shah A, Church MK, Holgate ST. Tumour necrosis factor alpha: a potential mediator of asthma. Clin Exp Allergy 1995;25:1038-44.

6 Moffatt MF, Cookson WOCM. Tumour necrosis factor haplotypes and asthma. Hum Mol Genet 1997;6:551-4.

7 Moffatt MF, James A, Ryan G, et al. Extended tumour necrosis factor/HLA-DR haplotypes and asthma in an Australian population sample. Thorax 1999;54:757-61

8 Trabetti E, Patuzzo C, Malerba G, et al. Association of a lymphotoxin alpha gene polymorphism and atopy in Italian families. J Med Genet 1999;36:323-5.

9 Chagani T, Pare PD, Zhu S, et al. Prevalence of tumor necrosis factor- $\alpha$ and angiotensin converting enzyme polymorphisms in mild/moderate and fatal/ near-fatal asthma. Am J Respir Crit Care Med 1999; 160:278-82. 
10 Li Kam WA TC, Mansur AH, Britton J, et al. Association between $\alpha$-308 tumour necrosis factor promoter polymorphism and bronchial hyperreactivity in asthma. Clin Exp Allergy 1999;29:1204-8.

11 Lovis R, Leyder E, Malaise M, et al. Lack of association between adult asthma and the tumour necrosis factor alpha-308 polymorphism gene. Eur Respir J 2000; 16:604-8.

12 Winchester EC, Millwood IY, Rand L, et al. Association of the TNF-alpha-308 $(G \rightarrow A)$ polymorphism with self-reported history of childhood asthma. Hum Genet 2000;107:591-6.

13 Zhu SK, Chan-Yeung M, Becker AB, et al. Polymorphisms of the IL-4, TNF $\alpha$, and $\mathrm{F}_{\mathrm{C} \in \mathrm{RI}} \beta$ genes and the risk of allergic disorders in at-risk infants. Am J Respir Crit Care Med 2000;161:1655-9.

14 Lin YC, Lu CC, Su HJ, et al. The association between tumor necrosis factor, HLA-DR alleles and lgE-mediated asthma in Taiwanese adolescents. Allergy 2002;57:831-4

15 Witte JS, Palmer $\sqcup, \mathrm{O}^{\prime}$ Connor RD, et al. Relationship between fumour necrosis factor polymorphism TNF $\alpha-308$ and risk of asthma. Eur J Hum Genet 2002;10:82-5.

16 Buckova D, Holla LI, Vasku A, et al. Lack of association between atopic asthma and the tumor necrosis factor alpha-308 gene polymorphism in a Czech population. J Invest Allergol Clin Immunol 2002;12:192-7.

17 Gao JM, Lin YG, Qiu CC, et al. The association between tumor necrosis factor $\alpha$ gene polymorphism and asthma. Chin Med Sci J 2003;18:248-53.

18 Di Somma C, Charron D, Deichmann K, et al. Atopic asthma and TNF-308 alleles: linkage disequilibrium and association analyses. Hum Immunol 2003;64:359-65

19 Beghe B, Padoan M, Moss CT, et al. Lack of association of HLA class I genes and TNF alpha-308 polymorphism in tolvene diisocyanate-induced asthma. Allergy 2004;59:61-4.

20 Gentile DA, Doyle WJ, Zeevi A, et al. Association between TNF- $\alpha$ and TGF- $\beta$ genotypes in infants and parental history of allergic rhinitis and asthma. Hum Immunol 2004:65:347-51.

21 Sandford AJ, Chan HW, Wong GWK, et al. Candidate genetic polymorphisms for asthma in Chinese schoolchildren from Hong Kong. Int J Tuberc Lung Dis 2004;8:519-27.

22 Shin HD, Park BL, Kim LH, et al. Association of tumor necrosis factor polymorphisms with asthma and serum total lgE. Hum Mol Genet 2004; 13:397-403.

23 Wang TN, Chen WY, Wang TH, et al. Gene-gene synergistic effect on atopic asthma: tumour necrosis factor- $\alpha-308$ and lymphotoxin- $\alpha-\mathrm{Ncol}$ in Taiwan's children. Clin Exp Allergy 2004;34:184-8.

24 Bilolikar H, Nam AR, Rosenthal M, et al. Tumour necrosis factor gene polymorphism and childhood wheezing. Eur Respir J 2005;26:637-46.

25 Randolph AG, Lange C, Silverman EK, et al. Extended haplotype in tumor necrosis factor gene cluster is associated with asthma and asthma-related phenotypes. Am J Respir Crit Care Med 2005;172:687-92.

26 Berlin JA, Longnecker MP, Greenland S. Meta-analysis of epidemiologic dose-response data. Epidemiology 1993;4:218-28.
27 van Houwelingen HC, Arends LR, Stijnen T. Advanced methods in metaanalysis: multivariate approach and meta-regression. Stat Med 2002;21:589-624.

28 Thompson SG, Higgins JP. How should meta-regression analyses be undertaken and interpreted? Stat Med 2002;21:1559-73.

29 Higgins JP, Thompson SG. Quantifying heterogeneity in a meta-analysis. Stat Med 2002;21:1539-58

30 Light R, Pillemer D. Summing up: the science of reviewing research. Cambridge, MA: Harvard University Press, 1984.

31 Begg CB, Mazumdar M. Operating characteristics of a rank correlation test for publication bias. Biometrics 1994;50:1088-101.

32 Egger M, Smith GD, Schneider M, et al. Bias in meta-analysis detected by a simple, graphical test. BMJ 1997;315:629-34.

33 Cardaba B, Moffatt MF, Fernandez E, et al. Allergy to Dermatophagoides in a group of Spanish gypsies: genetic restrictions. Int Arch Allergy Immunol 2001; 125:297-306.

34 Castro J, Telleria JJ, Linares $\mathrm{P}$, et al. Increased TNFA*2, but not TNFB*1, allele frequency in Spanish atopic patients. J Invest Allergol Clin Immunol 2000;10:149-54.

35 Immervoll T, Loesgen S, Dutsch G, et al. Fine mapping and single nucleotide polymorphism association results of candidate genes for asthma and related phenotypes. Hum Mutat 2001;18:327-36.

36 Izakovicova HL, Vasku A, Izakovic V, et al. The interaction of the polymorphisms in transporter of antigen peptides (TAP) and lymphotoxin alpha (LT-alpha) genes and atopic diseases in the Czech population. Clin Exp Allergy 2001;31:1418-23.

37 Noguchi E, Yokouchi Y, Shibasaki M, et al. Association between TNFA polymorphism and the development of asthma in the Japanese population. Am J Respir Crit Care Med 2002;166:43-6.

38 Sandford AJ, Chagani T, Weir TD, et al. Susceptibility genes for rapid decline of lung function in the Lung Health Study. Am J Respir Crit Care Med 2001; 163:469-73.

39 Wilson AG, de Vries N, Pociot F, et al. An allelic polymorphism within the human tumor necrosis factor $\alpha$ promoter region is strongly associated with HLA A1, B8, and DR3 alleles. J Exp Med 1993;177:557-60.

40 loannidis JPA, Ntzani EE, Trikalinos TA. 'Racial' differences in genetic effects for complex diseases. Nat Genet 2004;36:1312-8.

41 Bayley JP, Ottenhoff THM, Verweii, CL. Is there a future for TNF promoter polymorphism? Genes Immun 2004;5:316-29.

42 Hersh CP, Dahl M, Ly NP, et al. Chronic obstructive pulmonary disease in $\alpha_{1}$-antitrypsin PI MZ heterozygotes: a meta-analysis. Thorax 2004;59:843-9.

43 Contopoulos-loannidis DG, Manoli EN, loannidis JPA. Meta-analysis of the association of $\beta 2$-adrenergic receptor polymorphisms with asthma phenotypes. J Allergy Clin Immunol 2005;115:963-72.

44 Gao PS, Huang SK. Genetic aspects of asthma. Panminerva Med 2004;46:121-34. 